\title{
Technologies Teacher Educators Model to Pre-Service Teachers in Methods Courses
}

\author{
Gilbert Kalonde $^{1}$ \\ ${ }^{1}$ Department of Education, Montana State University Bozeman, Bozeman, USA \\ Correspondence: Gilbert Kalonde, Ph.D., Department of Education, Montana State University Bozeman, 212 Reid \\ Hall, PO Box 172880, MT 59717, USA. Tel: 406-994-5775.
}

Received: April 29, 2016

Accepted: June 16, 2016

Online Published: July 20, 2016

doi:10.5430/irhe.v1n2p113

URL: http://dx.doi.org/10.5430/irhe.v1n2p113

\begin{abstract}
The purpose of this study was to identify technologies teacher educators familiarize preservice teachers to in teacher education programs in the methods courses. Ninety teacher educators at two Midwestern universities were surveyed and interviewed for the study. Results showed that very few technologies are used by a vast majority of teacher educators. From over 100 types of technologies, results showed 7 as mostly used, 7 moderately used, and over 80 were minimally or not used at all. The study also found that, regardless of experience or tenure, teacher educators model technology similarly. The results have an implication on K-12 teachers, integration technology in their classrooms.
\end{abstract}

Keywords: teacher preparation, teacher knowledge, technology integration, professional development

\section{Introduction}

Research has shown that the use of technology in teacher education programs helps better prepare future teachers to integrate technology in the classrooms for instructional purposes (Fullan, 1999. Resta (2002) stated that it is essential for preservice teachers to immerse in technology-rich instructional environments throughout their teacher education program in order to ensure they gain comfort and competence in integrating new and different teaching tools into their classrooms. Studies have shown that teachers' comfort level with such teaching tools like technology influences the frequency at which they use these tools in lessons (Jahnke \& Kumar, 2014; Al-Bataineh, Anderson, Toledo, and Wellinski, 2008). Additionally, teachers' confidence in mastering the use of new tools and their perception of the usefulness of the old and new tools is an essential factor in their intention to use them in teaching (Holden \& Rada, 2011). In this study, the word "use" means educator use/d technology for instructional purposes and preservice teachers learn the use of the technology through observing the way it is used pedagogically while the word "model" is the deliberate process of familiarizing the learner to such technologies for pedagogical use in K-12 classrooms.

When teachers are slow to accept and adopt new tools, in this case technology, and fail to take ownership of technology initiatives, the use and impact of technology on learning is reduced (Herro et al., 2013). This also is true with teacher educators in their usage of technology in the methods courses in the teacher education programs. Preservice teachers are presumed ill prepared to use technology in the classroom due to lack of proper familiarization while in the teacher education programs. Teachers and teacher educators are typically considered agents of educational technology change. As with any other subject or activity in school, teachers have a profound influence on students' attitudes toward technology and its usage. Several studies have been done on K-12 teachers' integration of technology in the classroom, with a variety of questions asked and some of these questions answered. However, what has rarely been addressed is the impact and influence teacher educators' technology integration knowledge and technology modeling in methods courses have on preservice teachers' technology integration in K-12 classrooms. The International Society for Technology in Education (ISTE) has taken a critical step in showing the way to integrate technology by providing standards that describe technology competencies for both in-service and pre-service teachers. In particular, the ISTE standards require that assistive technology be addressed like any other technology in teacher education programs (ISTE, 2002). This implies that general education teachers must be trained to meet students' technological needs and be able to use practices that support learning, assessment, and participation of students with mild disabilities in inclusive classrooms. Some findings have been reported on how teachers are using and enhancing instructions using 
technology. However, there is a lack of studies and evidence that characterize teacher educators' usage, integration, and modeling of technology in teacher education programs. Therefore, the goals of this study were to identify instructional technologies teacher educators use and familiarize preservice teachers to in methods courses in teacher education programs; and to investigate if preservice teachers are familiarized to various assistive and instructional technologies. The ultimate goal was to illustrate the need for teacher educators to make use of various technologies in methods courses and to demonstrate technology integration for pedagogy in methods courses so as to provide purposeful guidance. Based on the goal of examining technologies teacher educators use and model to preservice teachers in the methods courses in teacher education programs, this study addresses the question: What technologies do teacher educators use, model and familiarize preservice teachers with in the methods courses?

Literature on technology in education have shown that most studies discuss teaching with technology have focused on teacher perceptions and attitude towards technology integration for general and inclusive classrooms (e. g. Zhang \& Espinoza, 1998). Other studies have focused on teachers' self-efficacy which has been used as a highly reliable measure for predicting the integration and implementation of technology in general education (Curts, Tanguma \& Peña, 2008; Lumpe \& Chambers, 2001; Morales, Knezek \& Christensen, 2008; Niederhauser \& Perkmen, 2008). However, evidence suggests that preservice teachers do not feel adequately prepared to effectively integrate technology in their classrooms (e.g., Drent \& Meelissen, 2008; Kay, 2006). Evidence points to teacher education programs concerning the need for professional development to facilitate successful technology integration practices in the methods courses (Buell, Hallam, Gamel-McCormick \& Scheer, 1999; Smith \& Dlugosh, 1999; Smith \& Smith, 2000). Despite this, there seem to be no studies that have examined how general education teacher educators model technology integration in their teaching methods courses. This study begins to fill this gap by identifying types of technologies teacher educators familiarize preservice teachers to in methods courses.

\section{Literature Review}

Research has also shown that there are several types of technologies that are being developed for both assistive and instructional purposes. AbleData (http://www.abledata.com/) provides a database of nearly 40,000 searchable assistive technology products from low-tech to high-tech devices. These technologies include computers and other electronic teaching tools: hardware and software (e.g., Smart boards, clickers, notebooks, iPads, and projectors), several types of assistive technologies for physical use and other inclusive technologies, and specialized educational software. There are also information resources that come with these tools which include online resources, encyclopedias, research databases, computational software (like SPSS), GeoGebra, and other technologies.

Technology integration should enable students (Preservice Teachers and K-12) to use an array of technologies just as easily as they make use of other learning tools such as books, paper and pencil (Cakir \& Yildirim, 2009; Hew \& Brush, 2007). Barron, Kemker, Harmes, and Kalaydjian (2003) found that technology use had increased in classrooms across the nation, supposedly due to increased levels of accessibility and skill, as well as favorable policy environments from school administrators to federal leadership.

The cost of educational technology is an important consideration in evaluating its value in classrooms. School districts have made multimillion dollar investments in educational technologies in the belief that it will lead to improved teaching and learning and to the development of essential skills for K-12 students (Bebell, O'Dwyer, Russell, and Hoffman, 2010). And examples of the investment involved, large school districts such as San Diego Unified School District (California) and McAllen Independent School District (Texas) have each purchased over 25,000 iPads at a cost of over $\$ 15$ million (Rhor, 2013). To make these massive investments worthwhile and enhance educational outcomes in the manner intended (Bebell et al., 2010), teacher educators must help preservice teachers to be ready for these technologies before encountering them in schools. Educational technology studies often focus on access to technology rather than measuring actual use; however, a variety of studies demonstrate that despite robust access, technologies' actual use might be low due various factors (Bebell et al., 2010).

A number of factors have been identified that explain teachers' failure to use technology in their classrooms. Among these factors is that teachers feel poorly prepared to use technology in the classrooms. Some studies have demonstrated that beginning teachers feel that they were not well-prepared to effectively use technology in their classrooms (e.g., Sang, Valcke, van Braak, \& Tondeur, 2010; Tearle \& Golder, 2008). Evidence shows a gap between what preservice teachers are taught in their courses and how teachers use technology in a real classroom environments (Ottenbreit-Leftwich, Glazewski, Newby, \& Ertmer, 2010; Pope, Hare, \& Howard, 2002). Findings suggest that technology is mostly under-used by preservice teachers and beginning teachers (Dawson, 2008; 
Kirschner \& Selinger, 2003). Aprt from ill preparation, several other factors influence new teachers to adopt technology, and among these is the quality and quantity of preservice technology exposure and experiences included in their teacher education programs (Agyei \& Voogt, 2011; Drent \& Meelissen, 2008).

Other researchers have classified the factors to technology adoption and use in the classroom into two categories: extrinsic and intrinsic. Ertmer (1999) referred to extrinsic barriers such as access, time, support, resources and training as first-order, and cited, and intrinsic barriers such as attitudes, beliefs, practices and resistance as second-order. Extrinsic barriers are defined as those that are related to organizations rather than individuals and intrinsic barriers as those related to insufficient access to technology (for example in the teacher education programs, e.g., Al-Alwani, 2005; Dawson, 2008), and lack of necessary technology skills (e.g., Teo, 2009).

Addressing these barriers in teacher programs may not mean that preservice teachers will be adequately prepared to successfully integrate technology into their classrooms (Kirschner \& Selinger, 2003). Studies have pointed out that to prepare preservice teachers for effective technology integration, teacher educators need to help them to build knowledge of good pedagogical practices, technical skills, and content knowledge, and how to relate these concepts to one another, as well as explicit and implicit exposure to technology use with classroom practices (Koehler \& Mishra, 2009).

Several studies have proposed that technology skills and familiarization should be integrated throughout teacher education programs to afford preservice teachers with technology skills and experiences needed to teach classes using technology to specific content areas (e.g., Niess, 2005). Other studies have also stated that technology integration needs to be incorporated in teacher training systemically throughout the program rather than presented in separate "unconnected" courses (Polly, Mims, Shepherd, \& Inan, 2010; Strudler, Archambault, Bendixen, Anderson, $\&$ Weiss, 2003). These studies support the Thompson, Schmidt, and Davis, (2003) guidelines on how preservice teachers within teacher education programs need to observe appropriate models of technology integration and practices in the classroom.

In a study by Tondeur, van Braak, Sang, Voogt, Fisser, and Ottenbreit-Leftwich (2012), they report 12 key themes for content and delivery methods that prepare preservice teachers to integrate technology into their future classrooms. The findings were broken into two parts: (1) seven key themes related to the preparation of preservice teachers and, (2) five key themes were about conditions necessary to implement programs such as technology integration at the teacher education level. Some of these themes are: aligning theory and practice; using teacher educators as role models; reflecting on attitudes about the role of technology in education; scaffolding authentic technology experiences, and scaffolding authentic technology experiences including those for inclusive classrooms, namely assistive technologies. However, contrary to the suggestions by Tondeur et al (2012), Russell, Bebell, O'Dwyer and O'Connor (2003) conducted a survey of 2,894 teachers in 22 Massachusetts districts to examine the extent to which technology is used in and out of the classroom for instructional purposes. The study found that teachers generally used technology more for preparation and communication and less for instructional delivery or learning activities. However, the survey also found that among teachers who were new to teaching as compared with more experienced colleagues, new teachers reported higher levels of comfort with technology and used technology more for preparation while the more experienced teachers used technology more often in the classroom for instructional delivery.

Therefore, effective use of technology to support instruction is associated with preservice teachers' understanding of different modes of technology use, basic understandings of technologies, beliefs about instruction, and ability to motivate students to use instructional technologies (Maddux \& Cummings, 1986; MacArthur, 2001). However, the findings above have not discussed how the skills for effective usage and abilities are developed, how teacher educators influence preservice teachers, or how to influence teacher educators' foundational scope in order that learning technologies are fully reflected in their teaching (Jordan, Shwartz \& McGhie-Richmond, 2009). Even if these are discussed extensively, what also is missing is the knowledge on the technologies being used and those not being used in the methods courses at teacher preparation levels.

Previous studies have touched on various aspects of technology integration processes, but have not gone further to find out what technologies teacher educators are using and modeling to preservice teachers. Therefore the findings in this study gives us a foundation to discuss technology integration from the teacher educators' perspective. The findings provided will help professional development providers, teacher education programs, teacher educators, accreditation agencies and teachers in general to better use, model and teach classroom technology integration. 


\section{Methods and Participants}

For this study, ninety (90) teacher educators from two large Midwestern universities in teacher education programs responded to a purposefully selected inventory for instructional and Assistive technologies. Quantitative and qualitative questions had them identify technologies they use in their methods courses. The study used a concurrent mixed methods research design with simple descriptive statistics. Qualitative data were analyzed using open-coding. The Technology Inventory Checklist ranged from older technologies to the latest releases.

\subsection{Participants}

Participants in this study were instructors, lecturers, assistant professors, associate professors and professors, with Masters or Doctorate degrees in specialty areas. Participants taught teaching methods courses in the following different subject areas: English Education; Mathematics Education; Science Education; Early childhood Education; Technical Education; Agriculture Education; Special Education; Art Education; Elementary Education; Family and Consumer Science Education; and Business, Marketing and Computer Education.

\subsection{Procedure}

The Technology Inventory Checklist ("Inventory"), devised by the researcher, listed technologies that are common in both general and inclusive classrooms. Teacher educators were asked to place a check mark in boxes to indicate technologies they have used before or modeled for the preservice teachers in their methods courses. They were also asked to state the course or topic in which they had used that technology. Teacher educators also had an opportunity to add any other technologies they have used in their methods courses that were not on the inventory. The second section of the data collection had six open-ended questions about the respondents' integration of technology in their methods courses. The open-ended responses provided some explanations to the quantitative results.

\subsection{Limitations}

Potential differences among respondents in their experiences, methods used in different subject content areas, interest in inclusiveness, and technologies used for the particular subject are potential limitations. Participation in the study by subjects was voluntary, and a sample of convenience was used. Participants were teacher educators teaching methods courses in the teacher education programs. It was not possible for the researcher to randomize participants from this group. One other limitation is the quality of modeling of technologies in the methods courses. Therefore, the results of this study may not be generalized beyond this group of teacher educators.

\section{Results}

\subsection{Technologies Teacher Educators Use in Methods Courses}

The primary goal of this study was to investigate technologies preservice teachers are familiarized to in their methods courses. Through qualitative and some quantitative content analysis, the researcher identified types of technologies teacher educators used and taught to preservice teachers in methods courses through a process of organizing and classifying the data to identify themes and the frequency with which each listed technology was used by the participants.

The results of the study show the types of technologies teacher educators use and teach with preservice teachers in methods courses. The first part of the study presents results from the open-ended questions to which participants were asked to list technologies they use in their methods courses. The second section presents results from the Inventory and participants' additions to that list. From the frequency of the selections, the researcher classified the technologies into "highly used," "moderately used," "little used" and "least used". The classifications (Highly used, moderately used, lowly used and least used) were based on the number of participants who stated that they use or have used the technology.

For the open-ended questionnaire, participants were asked to name technologies they use in their methods courses. In their responses, participants listed several technologies but the most used were videos, PowerPoint, Smart boards, the internet, Desire to Learn, computers, Elmo and iPads. Most of the technologies listed were instructional by nature. However, $10 \%$ of respondents specifically mentioned assistive technologies in their responses. The assistive technologies mentioned were Text-To-Speech, Thinking Reader, Magnifiers, Touch Technology, Interactive Learning Objects, Simulations, and PowerPoint with voice over. Respondents were also specifically asked what "assistive" and "instructional" technologies they have used in their methods courses. Six respondents did not respond to this question at all. Three respondents stated that they don't use any technology in their methods courses. One respondent identified use of Universal Design for Learning (UDL), but did not specify the technologies used. 
Table 1. Technologies teacher educators penciled in as used in methods courses

\begin{tabular}{llc}
\hline $\begin{array}{l}\text { Types of Technology } \\
\text { integrated }\end{array}$ & N & \% of citation \\
\hline Video & 42 & 47.0 \\
PowerPoint & 30 & 33.0 \\
Smart board & 27 & 30.0 \\
Internet & 21 & 23.0 \\
D2L & 21 & 23.0 \\
Computer & 15 & 17.0 \\
Elmo & 15 & 17.0 \\
iPad & 12 & 13.0 \\
Audio & 12 & 13.0 \\
Simulations & 9 & 10.0 \\
Prezi & 9 & 10.0 \\
Email Service & 9 & 10.0 \\
Word Processers & 9 & 10.0 \\
\hline
\end{tabular}

Table 2 also shows the number of teacher educators who reported having used a given technology in their teacher education methods courses. As evident in table 2, very few technologies were "highly used," as defined by technologies used by the majority of teacher educators in their methods courses. Specifically, only 8\% (7) types of technologies listed in the Inventory (Computers, LCD Projectors, Word Processors, Smart Boards, Desire to Learn, Blackboard, and Google Docs) fell into this category. For example, $87 \%$ of teacher educators said they use computer and LCD Projectors in their methods courses.

Table 2. Highly used technologies in methods courses by teacher educators

\begin{tabular}{llcc}
\hline & Type of Technology Used & $\mathrm{N}$ & \% of users \\
\hline Highly used Technologies & Computer & 78 & 87.0 \\
by Teacher Educators by & LCD Projector & 78 & 87.0 \\
percentage & Word Processor & 66 & 73.0 \\
& Smart Board & 66 & 73.0 \\
& Desire to Learn & 66 & 73.0 \\
& Blackboard & 63 & 70.0 \\
& Google Docs & 54 & 60.0 \\
\hline
\end{tabular}

Thirteen technologies constituted the moderately used technologies (mid-range percentages), only $15 \%$ of the total technologies listed in the Inventory. These moderately used technologies fell between 53\% and 33\% reported as used by teacher educators (Online Tutorials, Computer Animations, Portable Word Processor, Electronic books, Low tech aids to find materials, Document Camera, Games, Magnifiers, Large Print Books, Software for Organization of Ideas and Studying, Multimedia Software for expression of ideas, Multimedia Software for expression of ideas, and Computer Simulations). Many of the assistive technologies fell into this category. Examples included Multimedia Software for expression of ideas, Low tech aids to find materials (i.e., index tabs), Magnifiers, Software for Organization of Ideas and Studying, and Electronic books. 
Table 3. Moderately used technologies in the methods courses

\begin{tabular}{llcc}
\hline & Type of Technology Used & $\mathrm{N}$ & \% of users \\
\hline Moderately used & Online Tutorials & 48 & 53.0 \\
Technologies by Teacher & Computer Animations & 48 & 53.0 \\
Educators by Percentage & Portable Word Processor & 39 & 43.0 \\
& Electronic books & 39 & 43.0 \\
& Low tech aids to find materials (i.e., & 39 & 43.0 \\
& index tabs) & & \\
& Document Camera & 39 & 43.0 \\
& Games & 39 & 43.0 \\
& Magnifiers & 36 & 40.0 \\
& Computer Simulations & 36 & 40.0 \\
& Software for Organization of Ideas and & 33 & 37.0 \\
& Studying & & \\
& Multimedia Software for expression of & 30 & 33.0 \\
& ideas & & \\
\hline
\end{tabular}

Table 3 shows that slightly more technologies used in methods courses were used moderately, but fewer teacher educators have used or use them.

Most of the technologies listed in the Inventory fell into as the little used category (comprising Magnifiers, Computer simulations, Software for Organization of Ideas and Studying, Multimedia Software for expression of ideas, and Large Print books). This category had 24 technologies (23\%) of the total number of technologies used by teacher educators. The least used technologies covered those technologies that were only used by $0-9$ teacher educators in their methods courses. In this subgroup, a bigger percentage of assistive technologies are found. Combining the little and least used categories, over $54 \%$ (44) of technologies fell into these lower categories of usage in methods courses. The percentages of little and least used technologies ranged from $27 \%$ to $0 \%$.

Table 4. Little used technologies in methods courses by teacher educators

\begin{tabular}{llcc}
\hline & Type of Technology Used & N & \%of users \\
\hline Little used & Talking electronic device & 24 & 27.0 \\
Technologies by & Wiki & 24 & 27.0 \\
Teacher & Classroom Amplification & 21 & 23.0 \\
Educators by & Microphones & 21 & 23.0 \\
Percentage & Headsets & 21 & 23.0 \\
& Drills & 21 & 23.0 \\
& Communication Board with & 18 & 20.0 \\
& pictures/objects/letters/words & & \\
& Software for manipulation of objects/concept & 18 & 20.0 \\
& development & 18 & 20.0 \\
& Captioning & 18 & 20.0 \\
& Inspiration & 18 & 20.0 \\
& LiveText & 15 & 17.0 \\
& Adobe Connect & 15 & 17.0 \\
& Voice Recognition Software & 12 & 13.0 \\
& Screen Magnification Software (e.g. CloseView, & & \\
& Zoom Text) & 12 & 13.0 \\
& Kidspiration 3 & 12 & 13.0 \\
& Audacity & 12 & 13.0 \\
& Adapted paper (e.g. raised line) & 12 & 13.0 \\
& Word Prediction (e.g. Co: Writer) & 12 & 13.0 \\
& Electronic word book & 12 & 13.0 \\
\hline Talking Word Processor for multisensory typing & &
\end{tabular}




\begin{tabular}{|c|c|c|c|}
\hline \multirow{41}{*}{$\begin{array}{l}\text { Little (Least) } \\
\text { used } \\
\text { Technologies by } \\
\text { Teacher } \\
\text { Educators by } \\
\text { percentage }\end{array}$} & $\begin{array}{l}\text { Simple Voice Output Device (e.g. Big Mack, Cheap } \\
\text { Talk) }\end{array}$ & 9 & 10.0 \\
\hline & Scanner with Talking Word Processor & 9 & 10.0 \\
\hline & Abacus/ Math Line & 9 & 10.0 \\
\hline & Software with templates for math computation & 9 & 10.0 \\
\hline & Screen Magnifier (mounted over screen) & 9 & 10.0 \\
\hline & Screen Color contrast (e.g. CloseView) & 9 & 10.0 \\
\hline & Screen Reader (e.g. OutSpoken) & 9 & 10.0 \\
\hline & StoryBook Weaver Deluxe & 9 & 10.0 \\
\hline & Garage Band & 9 & 10.0 \\
\hline & Read Naturally & 9 & 10.0 \\
\hline & $\mathrm{CMS} / \mathrm{LMS}$ & 9 & 10.0 \\
\hline & Joystick with Onscreen Keyboard & 6 & 6.0 \\
\hline & $\begin{array}{l}\text { Alternate Keyboard (e.g. IntelliKeys, Discover } \\
\text { Board) }\end{array}$ & 6 & 6.0 \\
\hline & Electronic/Talking Electronic dictionary & 6 & 6.0 \\
\hline & Calculator with large keys and large LCD print out & 6 & 6.0 \\
\hline & Geogebra & 6 & 6.0 \\
\hline & PowerPoint & 6 & 6.0 \\
\hline & Bookbuilder & 6 & 6.0 \\
\hline & $\begin{array}{l}\text { Mouth Stick/Head Pointer with standard/alternate } \\
\text { keyboard }\end{array}$ & 3 & 3.0 \\
\hline & Micro Voice, Talking Picture Frame, Hawk & 3 & 3.0 \\
\hline & Voice Output Device with Levels & 3 & 3.0 \\
\hline & Voice output reminders for assignments & 3 & 3.0 \\
\hline & Talking Calculator & 3 & 3.0 \\
\hline & Braille Translation Software & 3 & 3.0 \\
\hline & Comic Life & 3 & 3.0 \\
\hline & Movie Maker & 3 & 3.0 \\
\hline & My Caert & 3 & 3.0 \\
\hline & EZ Records & 3 & 3.0 \\
\hline & Online repository & 3 & 3.0 \\
\hline & Widgit online & 3 & 3.0 \\
\hline & Prezi & 3 & 3.0 \\
\hline & Powtoon & 3 & 3.0 \\
\hline & Sound Recorder & 3 & 3.0 \\
\hline & Wii & 3 & 3.0 \\
\hline & Read.Write.Think & 3 & 3.0 \\
\hline & TV & 3 & 3.0 \\
\hline & ShowMe & 3 & 3.0 \\
\hline & Stationary Studio & 0 & 0.0 \\
\hline & Type to Learn 4 & 0 & 0.0 \\
\hline & Tracker with Onscreen Keyboard & 0 & 0.0 \\
\hline & Eye Gaze Board for communication & 0 & 0.0 \\
\hline
\end{tabular}

It is evident from the tables and information provided above that despite having fewer technologies reported as highly used in the methods courses, teacher educators reported using quite a variety of technologies. However, very few teacher educators used most of the highly used technologies.

\subsection{Qualitative Responses}

In the interview protocol, teacher educators reported using all sorts of different technologies as indicated on additions to the checklist and in response to open-ended questions. The most technologies provided in the interview protocol were iPads and PowerPoint. Here are some examples of responses by the respondents. For example respondent 1 
whose response discusses content and cost, but the technologies apparently belonged to the little used technologies, stated that;

"Technology must be applied according to the topic and subject matter. I use several technologies like more especially those that come from open source due to cost and sustainability. I use Geogebra, Moodle, Touch/Point technologies, for instance to find area of triangle, University provided online course management platforms and some assistive technologies that fall in the new standards in education. I also use Text-to-Speech, Voice Recognition software, and Concept Mapping software."

Another respondent provided her own list of technologies that she uses in her methods courses. Respondent 2 stated that;

"I use Text to Speech, iPads, Book Builders, Go-Animate, Historical Thinking, Google Docs and MediaConstructing Messages".

Although several technologies were mentioned by teacher educators interviewed, respondent 3 could not recall all the technologies used in the classrooms, and also stated that the best he/she does with technology in class were PowerPoint presentations. Respondent 5 although does not use a lot of technology, cited the need for professional development which in essence would familiarize teacher educators to newer or not known technologies. The respondent stated that;

"The only technology in my classes is only with PowerPoint and if possible I could use some technology training, I would be glad to have professional development that would help me updated with current technologies. I rarely use technology".

In response to question 3 of the interview protocol: Can you share some best examples of Assistive and General Educational technologies that you have used in your methods courses? Respondent 21 stated that in most cases, his/her teaching or the integration of technology is guided by the UDL. This response shows how so few technologies are used and familiarized to preservice teacher,

"Apart from the regular PowerPoint presentations, the use of Smart boards in the rooms equipped with such technologies, I also align my technology integration with the UDL Framework. I also use iPads, eBooks, and other scaffolding software to help students create multimedia curricular".

Other technologies mentioned by a respondent was that he used computers in almost all classes for PowerPoint and the internet to access the laws and standards as prescribed by the State Board of Education. The last one of the teacher educators to be interviewed (respondent 4) did not spend too much time on the question stating that he/she did not really focus on the inclusive part of the technologies she used in the methods courses, and also pointed out that due to some technological problems,

"I mostly use the Annenberg website and Live Text".

The statements above show that each teacher educator used some kind of technology in their classrooms, and the most uniform in these technologies was that they are mostly instructional and presentational, but none of the technologies mentioned in the interviews were assistive technologies.

What was found in this study was that there is no established pattern of technologies to use in methods courses. Although Universal Design for Learning gives a designed pathway with the six principles for inclusion, apparently there is no consensus on right or wrong technologies to use or model to preservice teachers in methods courses. Technologies used were mostly to aid presentation and instruction, not to model classroom use for preservice teachers

\section{Discussion and Conclusions}

Although outcomes from the study show that various technologies are used in teacher education methods courses. The study shows that a very limited number of technologies are being used by most teacher educators in methods courses. The qualitative findings showed that only 7 technologies could be categorized as highly used, with 13 other technologies revealed as moderately used in methods courses. These numbers are too low to substantively illustrate that preservice teachers are being adequately exposed or familiarized with educational technologies in the teacher education program. From a list of over 84 provided and participant add-in technologies, only 7 technologies emerging as highly used shows that preservice teachers are mostly exposed to only $8 \%$ of these technologies. The results also show that while some other technologies are being modeled to preservice teachers, the very low frequencies of the usage indicates inadequate educational technology preparation and demands the question of how much learning is influenced by these few technologies on both the teacher educators and the preservice teachers. 
Results also show that the least used technologies were mostly in the category of assistive technologies. Some technologies, as pertinent as they may be for instructional purposes at different levels of learning, were reported to have been used only by single participants. These results also show that higher the number of users of these technologies, the lower the number of technologies being used. There is a trend in the usage which shows that there are some technologies which are used frequently by teacher educators. In terms of software technologies, the findings show that most software mentioned as being used by teacher educators were content management software or those highly used for presentations, e.g. PowerPoint, Blackboard, and D2L.

While the issue of use and modeling of powerful and effective technologies by teacher educators with those preparing to be teachers is an important one, this study shows that preservice teachers are not being sufficiently familiarized with various technologies to adequately prepare them for the current state of technology standards as required by CAEP Standard 1.5 and the Common Core technology standards which realistically work in the classrooms to enhance learning activities. Also, the study found that despite the ISTE, Common Core Standards, federal and state regulations on integration of technology for inclusive classrooms (Education for All Handicapped Children Act (EHA) - Public Law 99-457, Individuals with Disabilities Education Act (IDEA), and NCLB (replaced by Every Student Succeeds Act - ESSA), very few teacher educators used or familiarized preservice teachers to inclusive technologies. The findings illuminate the need to make some adjustments in the way technologies are modeled and implemented in methods courses. One problem may be the way technology is acquired in teacher education programs, often relying too heavily on individual professors' grant funds to purchase them.

Studies have shown that preservice teachers' abilities to select, evaluate and use different technological resources can be improved and enhanced when they are exposed early to various technologies, which culminate in their preparedness and readiness to integrate technology into their classrooms. Several studies have also reported that preparing preservice teachers by offering courses for integrating technology can be effective and must be looked at positively in teacher education programs.

Whereas the current study provides a snapshot of the technologies being modeled to preservice teachers in methods courses, the findings also show that teacher educators might need more technology familiarization and exposure for their usage. Also, future research should look at the pedagogical effect of teachers' technology integration for K-12 students. In addition, future research should evaluate technology use in instruction among a more diverse population of participants.

\section{References}

Agyei, D. D., \& Voogt, J. M. (2011). Exploring the potential of the will, skill, tool model in Ghana: predicting prospective and practicing teachers' use of technology. Computers \& Education, 56, 91-100. http://dx.doi.org/10.1016/j.compedu.2010.08.017

Al-Alwani, A. (2005). Barriers to information technology in Saudi Arabia Science Education. Doctoral dissertation, the University of Kansas, Kansas.

Al-Bataineh, A., Anderson, S., Toledo, C., \& Wellinski, S. (2008). A study of technology integration in the classroom. International Journal of Instructional Media, 35(4), 381-386.

Barron, A. E., Kemker, K., Harmes, C., \& Kalaydjian, K. (2003). Large-scale research study on technology in K-12 schools: Technology integration as it relates to the national. Journal of Research on Technology in Education, 35(4), 489-507. http://dx.doi.org/10.1080/15391523.2003.10782398

Bebell, D., O'Dwyer, L., Russell, M., \& Hoffman, T. (2010). Concerns, considerations, and new ideas for data collection and research in educational technology studies. Journal of Research on Technology in Education, 43(1), 29-52. http://dx.doi.org/10.1080/15391523.2010.10782560

Buell, M. J., Hallam, R., Gamel-McCormick, M., \& Scheer, S. (1999). A survey of general and special education teachers' perceptions and in-service needs concerning inclusion. International Journal of Disability, Development and Education, 46(2), 143-156. http://dx.doi.org/10.1080/103491299100597

Çakir, R., \& Yildirim, S. (2009). What Do Computer Teachers Think About the Factors Affecting Technology Integration in Schools? Elementary Education Online, 8(3), 952-964.

Compeau, D. R., \& Higgins, C. A. (1995). Computer self-efficacy: Development of a measure and initial test. MIS Quarterly, 19, 189-211. http://dx.doi.org/10.2307/249688

Curts, J., Tanguma, J., \& Pena, C (2008). Predictors of Hispanic School Teachers' Self efficacy in the Pedagogical Use of Technology. Computers in the Schools. 25(1-2), 48-63. http://dx.doi.org/10.1080/07380560802157766 
Dawson, V. (2008). Use of information and communication technology by early career science teachers in Western Australia. International Journal of Science Education, 30(2), 203-219. http://dx.doi.org/10.1080/09500690601175551

Drent, M., \& Meelissen, M. (2008). Which factors obstruct or stimulate teacher educators to use ICT innovatively? Computers \& Education, 51, 187-199. http://dx.doi.org/10.1016/j.compedu.2007.05.001

Ertmer, P. (1999). Addressing first- and second-order barriers to change: Strategies for technology integration. Educational Technology Research and Development, 47(4), 47-61. http://dx.doi.org/10.1007/BF02299597

Fullan, M. (1999). Change forces: The sequel. Philadelphia: Falmer.

Herro, D., Kiger, D., \& Owens, C. (2013). Mobile technology: Case-based suggestions for classroom integration and teacher educators. Journal of Digital Learning in Teacher Education, 30(1), 30-40. http://dx.doi.org/10.1080/21532974.2013.10784723

Hew, K. F., \& Brush, T. (2007). Integrating technology into K-12 teaching and learning: Current knowledge gaps and recommendations for future research. Educational Technology Research and Development, 55, 223-252. http://dx.doi.org/10.1007/s11423-006-9022-5

Holden, H., \& Rada, R. (2011). Understanding the influence of perceived usability and technology self-efficacy on teachers' technology acceptance. Journal of Research on Technology in Education, 43(4), 343-353. http://dx.doi.org/10.1080/15391523.2011.10782576

International Society for Technology in Education. (2002). National educational technology standards for teachers: Preparing teachers to use technology. ISTE, Danvers, MA.

Jahnke, I., \& Kumar, S. (2014). Digital didactical designs: Teachers' integration of iPads for learning-centered processes. Journal of Digital Learning in Teacher Education, 30(3), 81-100. http://dx.doi.org/10.1080/21532974.2014.891876

Jordan, A., Schwartz, E., \& McGhie-Richmond, D. (2009). Preparing teachers for inclusive classrooms. Teaching and Teacher Education: An International Journal of Research and Studies, 25(4), 535-542. http://dx.doi.org/10.1016/j.tate.2009.02.010

Kay, R. H. (2006). Evaluating strategies used to incorporate technology into preservice education: A review of the literature. Journal of Research on Technology in Education, 38(4), 383-408.

Kirschner, P., \& Selinger, M. (2003). The state of affairs of teacher education with respect to information and communications technology. Technology. Pedagogy and Education, 12(1), 5-18. http://dx.doi.org/10.1080/14759390300200143

Koehler, M. J., \& Mishra. P. (2009). What is technological pedagogical content knowledge? Contemporary Issues in Technology and Teacher Education, (9)1, 60-70.

Kuchinke, K. (2000). Debates over the nature of HRD: an institutional theory perspective. Human Resource Development International, 3(3). 279-283. http://dx.doi.org/10.1080/13678860050128474

Lumpe, A., \& Chambers, E. (2001). Assessing teachers' context beliefs about technology use. Journal of Research on Technology in Education, 34, 93-107. http://dx.doi.org/10.1080/15391523.2001.10782337

MacArthur, C. (2001). Technology implementation in special education. In J. Woodward \& L. Cuban (Eds.), Technology, curriculum, and professional development (pp. 115-120). Thousand Oaks, CA: Corwin Press.

Maddux, C. D., \& Rhoda Cummings, R. (1986). Educational computing at the crossroads: Type I or Type II uses to predominate? Educational Technology, 26(7), 34-38.

Morales, C., Knezek, G., \& Christensen, R. (2008). Self-Efficacy Ratings of Technology Proficiency among Teachers in Mexico and Texas. Computers in the Schools, 25(1), 126-144.

Niederhauser, D. S., \& Perkmen, S. (2008). Validation of the intrapersonal technology integration scale: Assessing the influence of intrapersonal factors that influence technology integration. Computers in the Schools, 25(1-2), 98-111. http://dx.doi.org/10.1080/07380560802157956

Niess, M. L. (2005). Preparing teachers to teach science and mathematics with technology: Developing a technology pedagogical content knowledge. Teaching and Teacher Education, 21(5), 509-523. http://dx.doi.org/10.1016/j.tate.2005.03.006 
Ottenbreit-Leftwich, A., Glazewski, K., Newby, T., \& Ertmer, P. (2010). Teacher value beliefs associated with using technology: addressing professional and student needs. Computers \& Education, 55, 1321-1335. http://dx.doi.org/10.1016/j.compedu.2010.06.002

Polly, D., Mims, C., Shepherd, C. E., \& Inan, F. (2010). Evidence of impact: Transforming teacher education with preparing tomorrow's teachers to teach with technology (PT3) grants. Teaching and Teacher Education, 26, 863-870. http://dx.doi.org/10.1016/j.tate.2009.10.024

Pope, M., Hare, R. D., \& Howard, E. (2002). Technology integration: closing the gap between what teacher candidates are taught to do and what they can do. Journal of Technology and Teacher Education, 10(2), 191-203.

Resta, P. (Ed.) (2002). Information and Communication Technologies in Teacher Education: A Planning Guide. Proceedings at the general conference at UNESCO. Paris.

Rhor, M. (2013, Sept.). IPads expand time and space: More schools using tablets to break down traditional learning barriers. District Administration. http://www.districtadministration.com/article/ipads-expand-time-and-space-schools

Russell, M., Bebell, D., O'Dwyer, L., \& O'Connor, K. (2003). Examining teacher technology use: Implications for preservice and in-service teacher preparation. Journal of Teacher Education, 54, 297-310. http://dx.doi.org/10.1177/0022487103255985

Salend, J. S. (2005). Creating inclusive classrooms: Effective and reflective practices for all students (5th ed.). Columbus, Ohio: Pearson.

Sang, G., Valcke, M., van Braak, J., Tondeur, J. (2010). Student teachers' thinking processes and ICT integration: Predictors of prospective teaching behaviors with educational technology. Computers \& Education 54(1), 103-112. http://dx.doi.org/10.1016/j.compedu.2009.07.010

Serhan, D. (2009). Preparing preservice teachers for computer technology integration. International Journal for Instructional Media, 36(4), 439-447.

Smith, M. K., \& Dlugosh, L. L. (1999). Early childhood classroom teachers' perceptions of successful inclusion: A multiple case study. Paper presented at the Annual Conference for the American Educational Research Association. Montreal, Quebec: Canada.

Smith, M. K., \& Smith, K. E. (2000). I believe in inclusion, but...regular education early childhood teachers' perceptions of successful inclusion. Journal of Research in Childhood Education, 14(2), 161-180. http://dx.doi.org/10.1080/02568540009594761

Strudler, N., Archambault, L., Bendixen, L., Anderson, D., \& Weiss, R. (2003). Technology helping restructure educational access and delivery. Educational Technology Research and Development, 51(1), 41-56. Retrieved from http://www.jstor.org/stable/30220362

Tearle, P., \& Golder, G. (2008). The use of ICT in the teaching and learning of physical education in compulsory education: How do we prepare the workforce of the future? European Journal of Teacher Education, 31(1), $55-72$.

Teo, T. (2009). Examining the relationship between student teachers' self-efficacy beliefs and their intended uses of technology for teaching: A structural equation modeling approach. The Turkish Online Journal of Technology, 8(4), 7-16.

Thompson, A. D., Schmidt, D. A., \& Davis, N. E. (2003). Technology collaboratives for simultaneous renewal in teacher education. Educational Technology Research and Development, 51(1), 124-128. http://dx.doi.org/10.1007/BF02504519

Tondeur, J., Van Braak, J., Sang, G., Voogt, J., Fisser, P., \& Ottenbreit-Leftwich, A. (2012). Preparing preservice teachers to integrate technology in education: A synthesis of qualitative evidence. Computers \& Education, 59(1), 134-144.

Zhang, Y., \& Espinoza, S. (1998). Relationships among computer self-efficacy, attitudes toward computers, and desirability of learning computing skills. Journal of Research on Technology in Education, 30(4), 420-436. http://dx.doi.org/10.1080/08886504.1998.10782236 


\section{Appendix: Technology Inventory}

On this checklist, please put a check mark on the response that best fits your use of the particular technology in your methods courses. If you have used/taught pre-service teachers on how to use the technology, please check YES, if not please check NO in the box against the technology. There is no right or wrong answer on all of the items.

\begin{tabular}{|c|c|c|c|c|}
\hline \multicolumn{5}{|c|}{ Technology Inventory (Instructional \& Assistive) } \\
\hline & \multirow[t]{2}{*}{ Writing } & \multicolumn{2}{|c|}{$\begin{array}{l}\text { Have you used this } \\
\text { technology in your } \\
\text { methods course? }\end{array}$} & \multirow[t]{2}{*}{$\begin{array}{l}\text { Comments about the tool and the } \\
\text { topic or course in which it was used. }\end{array}$} \\
\hline & & YES & NO & \\
\hline 1 & Pencil/pen with adaptive grip & & & \\
\hline 2 & Adapted paper (e.g. raised line) & & & \\
\hline 3 & Slant board & & & \\
\hline 4 & Portable Word Processor & & & \\
\hline 5 & Computer & & & \\
\hline 6 & Joystick with Onscreen Keyboard & & & \\
\hline 7 & $\begin{array}{l}\text { Alternate Keyboard (e.g. IntelliKeys, } \\
\text { Discover Board) }\end{array}$ & & & \\
\hline 8 & $\begin{array}{l}\text { Mouth Stick/Head Pointer with } \\
\text { standard/alternate keyboard }\end{array}$ & & & \\
\hline 9 & $\begin{array}{l}\text { Head Mouse/Head Master/Tracker with } \\
\text { Onscreen Keyboard }\end{array}$ & & & \\
\hline 10 & Voice Recognition Software & & & \\
\hline \multirow[t]{2}{*}{11} & Word Prediction (e.g. Co: Writer) & & & \\
\hline & Composing Written Material & & & \\
\hline 12 & Electronic word book & & & \\
\hline 13 & $\begin{array}{l}\text { Electronic/Talking Electronic dictionary } \\
\text { (e.g. Franklin Bookman) }\end{array}$ & & & \\
\hline 14 & Word Processor & & & \\
\hline 15 & $\begin{array}{l}\text { Talking Word Processor for multisensory } \\
\text { typing }\end{array}$ & & & \\
\hline 16 & Voice Recognition Software & & & \\
\hline \multirow[t]{2}{*}{17} & $\begin{array}{l}\text { Multimedia Software for expression of } \\
\text { ideas }\end{array}$ & & & \\
\hline & Communication & & & \\
\hline 18 & $\begin{array}{l}\text { Communication Board with } \\
\text { pictures/objects/letters/words }\end{array}$ & & & \\
\hline 19 & $\begin{array}{l}\text { Eye Gaze Board (Eye Gaze } \\
\text { Communication) }\end{array}$ & & & \\
\hline 20 & $\begin{array}{l}\text { Simple Voice Output Device (e.g. Big } \\
\text { Mack, Cheap Talk, Voice in a Box) }\end{array}$ & & & \\
\hline 21 & Micro Voice, Talking Picture Frame, & & & \\
\hline
\end{tabular}




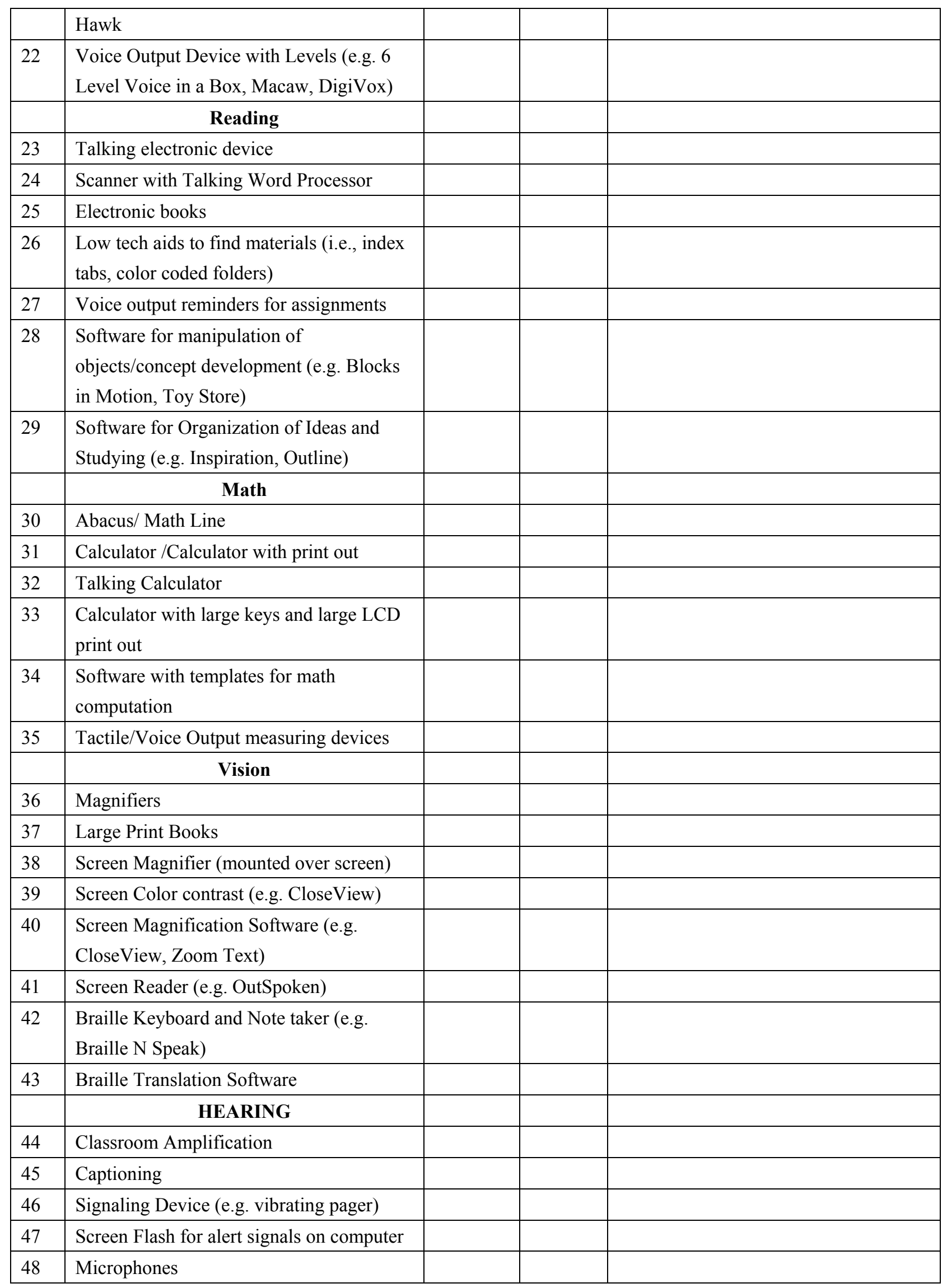




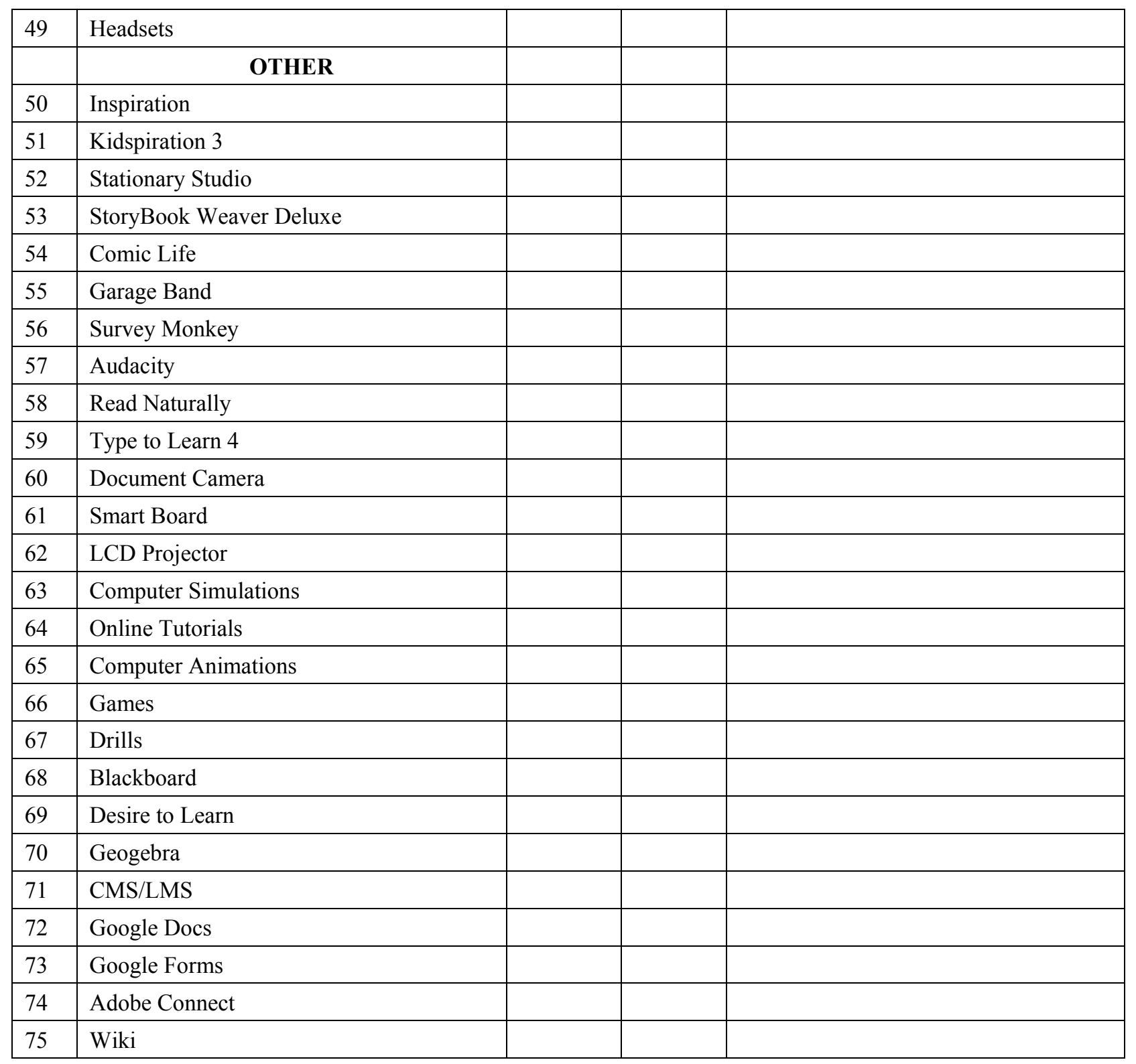

If there are any other technologies that you are using or have used in the recent past, please use the space below to list them.

Type of Technology

\section{Course used in}

